\title{
The Improvement of Metacognition of Chemistry Education Students using Metacognitive Learning Strategy
}

\author{
$1^{\text {st }}$ Parlan \\ Department of Chemistry, \\ Faculty of Mathematics \\ and Natural Science, \\ Universitas Negeri Malang, \\ Indonesia \\ parlan.fmipa@um.ac.id
}

\author{
$2^{\text {nd }}$ Suhadi Ibnu \\ Department of Chemistry, \\ Faculty of Mathematics \\ and Natural Science, \\ Universitas Negeri Malang, \\ Indonesia \\ parlan.fmipa@um.ac.id \\ $4^{\text {th }}$ Suharti \\ Department of Chemistry, \\ Faculty of Mathematics \\ and Natural Science, \\ Universitas Negeri Malang, \\ Indonesia \\ parlan.fmipa@um.ac.id
}

\author{
$3^{\text {rd }}$ Sri Rahayu \\ Department of Chemistry, \\ Faculty of Mathematics \\ and Natural Science, \\ Universitas Negeri Malang, \\ Indonesia \\ parlan.fmipa@um.ac.id
}

\begin{abstract}
Learning content of chemistry incluaes factual, conceptual, procedural, and metacognitive knowledge. To well master the learning content, students' metacognition is required. Students' metacognition can be formed and developed through learning. Metacognitive learning strategy is one of the strategies that can develop and improve the metacognition of learners. The aim of this research was to develop Metacognitive Learning Strategy (MLS) to improve metacognition Chemistry Education Students' (CES). The study adopt a development research design, the 4-D model by Thiagarajan, et al. (1974). The development process consisted four steps: define, design, develop, and disseminate. Content and construct validity of MLS have been assessed by three experts. The developed MLS would be subsequently applied in the learning to increase metacognition students of CES. Improved students metacognition skills were observed using a metacognitive awareness inventory (MAI) questionnaire (Schraw \& Dennison, 1994). The MLS that was developed have four steps (syntaxes), namely Preparing, Doing, Checking, and Assessing \& Followingup (PDCA). Validation results indicate that PDCA's MLS is appropriate for use in learning (reliability for relevance and consistency aspects are 0.89 and 0.88 respectively). Application of MLS in organic chemistry learning was able to increase students' metacognition of CES both metacognitive knowledge and metacognitive skills with $N$-Gain scores $(<\mathrm{g}\rangle) \quad 0.31$ and 0.35 respectively.
\end{abstract}

Keywords- metacognition, students' metacognition, metacognitive knowledge, metacognitive skills.

\section{INTRODUCTION}

Metacognition is an important aspect of learning because it is related to conceptual change, enables longer retention, and broader material applications, and is a significant predictor of academic success (Gabrijela and Velki, 2012). Metacognition has also become an important element in the efforts of students to gain a deep understanding of the concepts of chemistry and skill in problem solving (Cook, Kennedy, \& McGuire: 2013). Metacognition has been shown to lead to deeper, more durable, and more transferable learning (Bransford, Brown, \& Cocking, 2000). The metacognitive process improves learning with understanding. Learning with understanding allows the application of acquired knowledge in a new context.

One of the objectives of chemistry learning is to help students to construct knowledge and thinking skills so they can find the relationships between concepts in chemistry and using the understanding of those concepts to explain various phenomena in chemistry. One example is the relationship between molecular structure of a substance and its properties in meaningful learning (Cooper, Corley, and Underwood, 2013). The real facts show that the classroom teacher's teaching is still dominated by conventional approach. Conventional approaches are not in line with modern 
learning paradigm to develop an understanding of the relationship between the structures and properties of compounds. Learning experience of students cannot help to develop an adequate conceptual framework.

The research indicate that there are many students who have difficulties in relating the studied concept with other concepts. Understanding of interconnection between concepts in chemistry is still very low. Students still have difficulties explaining the properties of compounds based on their molecular structure. For example, most students assume that if a liquid boils there is a breaking of the covalent bonds in the molecule of the compounds. Many students still assume that if a substance melts (melts) there is a breaking of covalent bond (not an intermolecular bonds) (Smith and Nakhleh, 2011). Low student understanding of chemical learning content is one indicator of low students metacognition.

The future science teachers (including chemistry teachers) should be teachers who understand the learning content taught to their students. Therefore, teachers must understand chemistry concepts and the interrelationships between the concepts and to use them in teaching their students. A good understanding of science concepts is a prerequisite for science teachers to be able to teach their students well. Teachers who understand the material well can explain the concepts properly and use the best learning practices that support their students in the construction of concepts and to develop abstract concepts understanding (NSTA, 2012).

Learning that is explicitly designed to improve knowledge and its metacognitive skills can improve students' learning outcomes and the ability to solve problems (Delvechio, 2011). It is widely believed that metacognition is an important mediator for learning effectiveness, especially at higher education. Individuals with good metacognition ability can understand their learning objectives well, plan appropriate learning methods, and monitor their learning outcomes to get better understanding. However, the majority of students lack the metacognitive knowledge and sufficient regulatory abilities to adequately manage their learning (De Backer, Hilde, \& Martin: 2012).

Metacognitive skills provide individualized learning that requires awareness of individual knowledge and understanding of how to extend knowledge (Kipins \& Hofstein, 2008). Individuals with better metacognitive awareness exhibit better learning outcomes than individuals with less metacognitive awareness (Tali \& Dar, 2014). Students who have good regulatory skills (metacognitive skills) show good learning outcomes as well.

Wilson \& Bai (2010) conducted a study of the relationship between teacher metacognitive knowledge and pedagogical understanding of metacognition. The results showed that the teacher's metacognitive knowledge had an impact on their metacognitive understanding. Teachers who have a better understanding of metacognition teach their students to be metacognitive, a complex understanding of metacognition and metacognition thinking strategies. Effective science learning not only improves learning, but also helps students to develop the metacognitive skills necessary to master higher levels of science and to reconstruct their conceptual knowledge and procedural strategies if necessary (Schraw, et al., 2006)

An important goal of education is to develop students' metacognitive abilities as lifelong learners. However, developing students' metacognition and classroom based assessment to develop student metacognition is a difficult and often time-consuming task (Thomas, 2003). Metacognition is a set of skills that enable students to be aware of how students learn, evaluate, and adapt skills to make their learning more effective. Flick and Tomlinson (2006) suggest that learning with cognitive strategies improves student performance on science inquiry assessment tasks.

The application of metacognitive strategies has a positive impact on long-term memory of students. Students who are taught with metacognitive strategies can remember more concepts and master better problem-solving processes. The application of metacognitive strategies also contributes positive impacts to students' problem solving skills (Beal, 2012; Cooper \& Urena, 2009). Other research results show that the development of metacognitive skills of CES can increase their awareness of how to learn and be responsible for their learning (Temel, et al., 2012).

Cook, et al. (2013) conducted a study on application of metacognitive strategies in the form of a study cycle consisting of five steps: preview, attendance, review, study, and assessment in basic chemistry courses. Most students have difficulty learning basic chemistry because it focuses on remembering facts and formulas rather than understanding the concepts and problem-solving skills. The application of metacognitive strategies can increase the effort from low-level thinking to higherorder thinking. Students who follow the learning with metacognitive strategies get better results and can change the habit as a result after getting new information about learning. 
Metacognitive strategy which was developed by Cook et al. (2013) has two weakness, there are: 1) the pre-class activities have not explicitly conditioned the students to relate to the prior knowledge needed to understand the new material. Actually, students' understanding of the prerequisite knowledge determines the quality of learning planned and implemented by students and lecturer. 2) in the final stages of learning, there is no assessment of the students' understanding of learning content. In addition, there wasn't following-up activities on learning outcomes associated with subsequent learning activities.

In this study an improved MLS was developed by modifying the strategy which was developed by Cook, et al (2013). The improved MLS was consisted of four steps. The validated learning strategy will be subsequently applied in learning to improve metacognition of CES.

\section{METHODS}

The development of metacognitive learning strategy follows the steps of 4-D model (Thiagarajan et al., 1974), which consists of four steps: define, design, develop, and disseminate.

Define

This stage aims to define the terms of learning. An analysis is done to set goals and limit learning materials. The defining stage includes the steps: 1) front-end analysis, 2) analysis of learners, 3) task analysis, 4) concept analysis, and 5) specification of learning objectives.

Front-end analysis was done to find out the needs and problems that occur in the instruction of organic chemistry, especially on the topic of relationship between structure and properties of organic compounds. The analysis was done by reviewing the learning outcomes of the students of CES in the last three years and followed by a discussion with colleagues of the lecturers of organic chemistry. This activity primarily aims to find fundamental problems experienced by students in studying the learning material especially the relationship between structure and properties of compounds, so that can be found appropriate strategies in organic chemistry for future learning. The results of the analysis concluded: 1) students' understanding of the structure and the properties of organic chemistry was still low, 2) the proportion of students who were succeeded to give an explanation that links two or more variables of each was very low $( \pm 25 \%), 3)$ the ability of students to answer the questions demanding higher order thinking skills was also still low (20-25\%). These facts indicate that the learning experience of the students has not provided an opportunity for them to develop their thinking skills. Therefore, it is necessary to develop a learning model that gives a meaningful learning experience so that it can develop students' thinking ability. This study is trying to develop a learning strategy that is believed to provide a meaningful learning experience to students.

Analysis of learner was done to know the character of the learners so that the development of learning design and the tools according to the character of the learners. CES in second semester are aged between 18-20 years. According to Peaget's intellectual development theory, they should have entered the stage of abstract thinking ability which is the highest level in Peaget's intellectual development theory. This analysis is also conducted to determine the knowledge base, learning experiences, and attitudes or behavior of learners. The task analysis is performed to identify the skills acquired by the learners and to determine the appropriate sub-skills in the lesson. Analysis was done to ensure that it comprehensively covers the tasks in the learning materials.

Concept analysis is done by identifying the main concepts studied on the topic of the relationship between structure and the properties of organic compounds. The concepts are bonding polarity, molecular polarity, acid-base strength, molecular force, boiling point, freezing point, solubility, and viscosity associated with the structure of the compound.

The goal specification of learning is to convert the results of the analysis of tasks and concepts into the stated objectives in the form of behavior. The formulated objectives are the reference in developing test constructs and instructional designs that are integrated into the learning materials to be used.

\section{Design}

The purpose of this stage is to define and design learning strategies that are MLS and learning tools. Activities undertaken at this stage are: 1) preparing tests, 2) selecting media, 3) format selection, and 4) preliminary design.

\section{Develop}

The purpose of this stage was to modify the prototype of learning materials. At the development stage, feedback is obtained from formative evaluation and the appropriate material. This stage consisted of two activities namely expert validation and development testing. 
Expert validation was conducted to obtain the necessary suggestions for the improvement of the MLS draft and learning tools. The validation instrument contains a statement requesting a judgement of a validator with 5 categories related to a Likert scale, i.e $5=$ very good, $4=\operatorname{good}, 3=$ enough, $2=$ less, and $1=$ very less. In addition, there is also a column asking for suggestions of the validator to further improve the development results.

Developmental testing involves testing material in a real situation of classroom learning.
Based on the responses and comments of students the MLS was then modified. Developmental testing is carried out on the learning of organic chemistry. This test is conducted to obtain information on the feasibility and applicability of MLS and tools developed according to the real conditions.

The research and development steps are presented in Table 1, which includes the steps, activities, objectives, and methods used.

Table 1 Development Steps

\begin{tabular}{|c|c|c|c|c|}
\hline No & Steps & Activities & Objectives & Methods \\
\hline 1 & $\begin{array}{l}\text { Preliminary } \\
\text { studies }\end{array}$ & $\begin{array}{l}\text { 1. Identify problems that } \\
\text { occur in chemistry learning } \\
\text { related to the model or } \\
\text { lecture strategy used. } \\
\text { 2. Review the literature } \\
\text { related to organic chemistry } \\
\text { learning and to improve } \\
\text { students' metacognition. }\end{array}$ & $\begin{array}{l}\text { To identify whether the } \\
\text { used strategy employed } \\
\text { has afforded the } \\
\text { opportunity for students } \\
\text { to develop their } \\
\text { metacognition. }\end{array}$ & 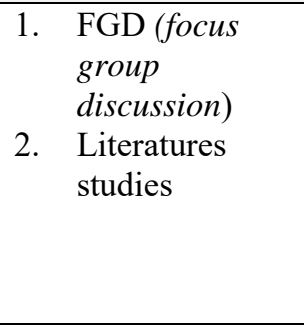 \\
\hline 2 & \multicolumn{4}{|c|}{ Development of learning strategy and tools } \\
\hline & $\begin{array}{l}\text { Development of } \\
\text { learning strategy }\end{array}$ & $\begin{array}{l}\text { 1. Develop metacognitive } \\
\text { learning strategy. } \\
\text { 2. Validate metacognitive } \\
\text { learning strategies } \\
\text { developed by experts. }\end{array}$ & $\begin{array}{l}\text { Establishment of a valid } \\
\text { learning pathway } \\
\text { (syntax) for } \\
\text { metacognitive learning } \\
\text { strategy. }\end{array}$ & \multirow[t]{2}{*}{$\begin{array}{l}\text { Research and } \\
\text { development }\end{array}$} \\
\hline & $\begin{array}{l}\text { Development of } \\
\text { tools }\end{array}$ & $\begin{array}{l}\text { 1. Develop of tools (learning } \\
\text { material, lesson plan, } \\
\text { instructional media, and } \\
\text { assessment) which } \\
\text { corresponds to the 4-D } \\
\text { model adapted from } \\
\text { Thiagarajan (1974). } \\
\text { 2. Validate learning tools by } \\
\text { expert. }\end{array}$ & $\begin{array}{l}\text { Establishment of a valid } \\
\text { learning tools and } \\
\text { support metacognitive } \\
\text { learning strategy }\end{array}$ & \\
\hline \multirow[t]{2}{*}{3} & Implementation & & & \\
\hline & Testing & $\begin{array}{l}\text { Testing metacognitive learning } \\
\text { strategies using pre and } \\
\text { posttest design. }\end{array}$ & $\begin{array}{l}\text { Knowing the } \\
\text { effectiveness of } \\
\text { metacognitive learning } \\
\text { strategies in improving } \\
\text { students metacognition }\end{array}$ & $\begin{array}{l}\text { Qualitative and } \\
\text { quantitative methods } \\
\text { (mix-methods) }\end{array}$ \\
\hline 4 & Dissemination & $\begin{array}{l}\text { The use of metacognitive } \\
\text { learning strategies and tools on } \\
\text { a wider scale. }\end{array}$ & $\begin{array}{l}\text { To expand the } \\
\text { application of } \\
\text { metacognitive learning } \\
\text { strategy. }\end{array}$ & $\begin{array}{l}\text { Publish on seminar } \\
\text { or journal }\end{array}$ \\
\hline
\end{tabular}

The steps for the preparation of the instructional design are presented in Table 2.

Table 2 The steps for the preparation of the instructional design. 


\begin{tabular}{|c|c|c|}
\hline Activities & Methods & Expected results \\
\hline $\begin{array}{l}\text { 1. Identify essential components } \\
\text { in metacognitive learning } \\
\text { 2. Develop metacognitive } \\
\text { learning steps } \\
\text { 3. Develop of metacognitive test } \\
\text { instrument }\end{array}$ & $\begin{array}{l}\text { Review literature (journals and } \\
\text { textbooks) on the use of } \\
\text { metacognitive learning strategies in } \\
\text { chemistry } \\
\text { Developing metacognitive learning } \\
\text { strategies } \\
\text { Adapting Metacognitive Awarreness } \\
\text { Inventory by Schraw \& Dennison } \\
\text { (1994) }\end{array}$ & 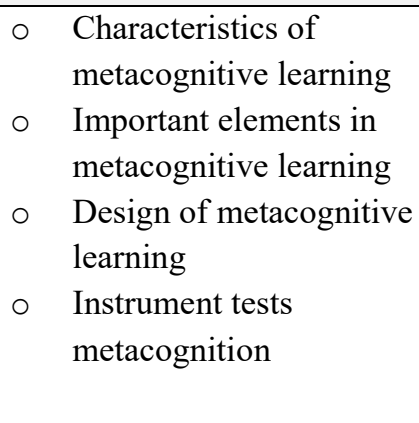 \\
\hline
\end{tabular}

The subject of this research are CES of 2016/2017 who have taken the Basic Chemistry I course. Development testing was conducted with three main stages, namely preparation, implementation and observation, and interpretation of results.

The instrument used in this research consists were: 1) validation instrument (content and construct), 2) metacognitive awwareness inventory (MAI), and 3) questionnaire for students. Increased students' metacognition is expressed by $\mathrm{N}$-gain score $<\mathrm{g}>$.

\section{RESULT AND DISCUSSION}

The developed MLS consists of four steps: Preparing, Doing, Checking, and Assessing and Following-up (PDCA). The developed steps adopted metacognitive strategies developed by Cook, et al. (2013) by adding the planning component at the beginning of the instruction and the follow-up component at the end of the instruction. The final result of the development of MLS is represented by Figure 1.

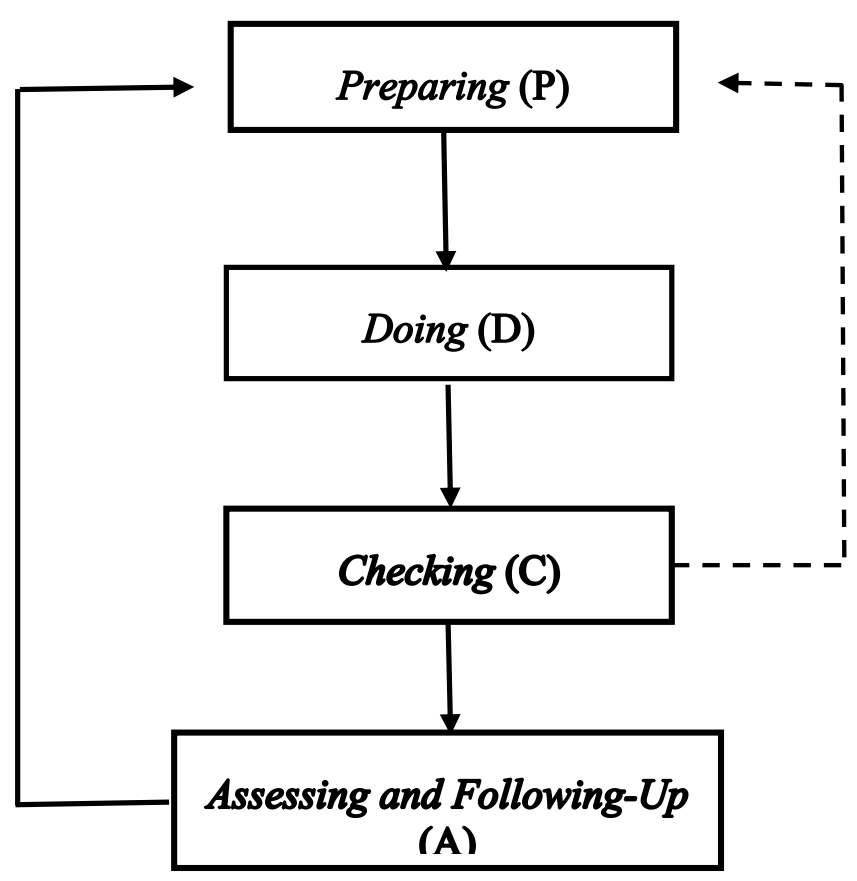

Figure 1. Stages of PDCA Matacognitive Learning Strategy

\section{Information:}


The learning steps of MLS are based on metacognitive theories so that the flow of learning activities experienced by students is a planned, organized, and monitored learning experience to provide opportunities for students to construct deep understanding. The learning steps that have been prepared are used as a reference for compiling learning tools. Based on the results of the developments that have been done is represented by Figure 1. Explanation of each step in metacognitive learning strategy PDCA described as follows.

\section{a. Preparing}

This stage is done before the learning in the classroom. Lecturers provide teaching materials/hand-outs to students and students are asked to do a preview of the material to be learned by marking important sections, underlining, summarizing, and reading \& interpreting images/tables/graphs that are beneficial to students when they attend classroom. Through the preview students can recognize patterns, increase interest, and encouragement to ask questions.

According to the Winne \& Hadwin (1998) model at this stage the student checks the learning environment to construct a given task profile. Such profiles intrinsically integrate the goal perceptions and attitudes about the task (Pintrich, et al., 1990) and other motivational information such as decisions about selfefficacy. The result of this stage is the idiosyncratic description of the task according to the students. After that, learners set goals and work plans to complete their tasks. Students then choose strategies and ways to accomplish the task. The preparing stage aims to prepare the students mentally to receive new material that is learned.

\section{b. Doing (Learning)}

At this stage students are involved in learning activities that have been designed in the previous stage. Lecturer facilitate students to engage in active learning through discussion, questioning, completion of assignments, presentations, and/or making concepts map. Through these activities students construct their understanding with the guidance of lecturer. According to meaningful learning, the introduction of the concept is more easily understood by the students if it is elaborated and developed from the general concept (global) towards a smaller/simpler concept.

In the learning process, lecturer give a discussion sheet or give problems to be discussed/resolved by students in groups. According to Vygotsky theory learners learn through interaction with others or more capable peers (Slavin, 2012). Through group learning it is expected that mutual learning happens among friends in groups or between groups. Lecturer monitor students learning activities, direct learning, and help students if they have difficulties.

\section{c. Checking (Monitoring)}

In this step the students are facilitated to check/review their learning. The review is done immediately after the instruction or even when the learning takes place to help the student recognize overlap materials between what are obtained in the class and what is read in the book, correct any misconceptions, and determine whether appropriate assistance and planning are required. In this step the student also checks whether the chosen method or learning method is appropriate. This step can overlap with the previous step, it can be done simultaneously with the previous step.

\section{d. Assesing and Following-Up}

At this stage the performance assessment/learning outcomes of learning tasks are performed. In addition, there is also an arrangement of emotional responses related to learning outcomes and experiences. Lecturer need to anticipate cognitive disagreement by constructing conceptual interrelationships through conceptual hierarchy.

Assessment helps students to know the achievement of learning (outcome) expressed in the form of learning objectives that have been formulated at the beginning of learning. The results of the assessment can be used by lecturer and students to obtain information about the strengths and weaknesses of learning process that has been done, so that the clear direction of 
what should be improved and can reflect on what should be done in learning.

The end of this step is the follow-up done by the lecturer with the students, e.g. whether additional tasks are required, whether remedial learning is required, or can be continued for the next material. If the final conclusions are chosen, so the learning plan is done starting the first step as before, so the four steps are repeated.

The four steps in PDCA MLS facilitate students to organize their learning well from planning, implementation and monitoring. If the four stages can be done well then the student learning becomes a whole learning activity by activating all the metacognition components they have. These three components of metacognition skills enable students to facilitate their learning Table 4 Activities of lecturers and students in learning with PDCA's MLS and ability (Schraw \& Moshman, 1995). Empirical studies show that students who learnt metacognitively show better results than those who do not use their metacognitive. Students who increasingly know the effectiveness of their learning strategies can reach higher learning outcomes in the future (Tali and Dar, 2014). Individuals who possess a high degree of metacognitive knowledge and have metacognitive skills are able to evaluate steps of their learning as soon as possible and change their tools or strategies to achieve goals (Akkar, et al., 2011).

The activities of lecturers and students in learning with PDCA's MLS are presented in Table 4.

\begin{tabular}{|c|c|c|}
\hline Step & Lecturer activities & Students activities \\
\hline $\begin{array}{l}\text { Phase 1: } \\
\text { Preparing }\end{array}$ & $\begin{array}{l}\text { 1. Convey the plan of learning activities. } \\
\text { 2. Providing teaching materials / hand-out to } \\
\text { students. } \\
\text { 3. Ask students to arrange the schedule and } \\
\text { how to learn. } \\
\text { 4. Ask students to study the teaching materials } \\
\text { and determine the purpose of studying the } \\
\text { material, identify important concepts to be } \\
\text { studied, identify relevant prerequisite } \\
\text { knowledge, identify concepts that have been } \\
\text { understood, summarize, make a list of } \\
\text { questions to ask in the classroom. }\end{array}$ & $\begin{array}{l}\text { 1. Reviewing teaching materials } \\
\text { 2. Setting learning goals } \\
\text { 3. Determine how to learn } \\
\text { 4. Prepare a learning schedule } \\
\text { 5. Identify important concepts to be } \\
\text { studied } \\
\text { 6. Identify relevant prior knowledge } \\
\text { knowledge } \\
\text { 7. Identify important concepts that } \\
\text { have been understood } \\
\text { 9. Make a summary } \\
\text { 9ake a list of questions to ask on } \\
\text { in the classroom. }\end{array}$ \\
\hline
\end{tabular}

\begin{tabular}{ll}
\hline Phase 2: Doing & Facilitating students to learn actively in the \\
(Learning) & classroom (presentations, discussions, asked- \\
& questions, and making notes / material \\
& summaries)
\end{tabular}

Students engage in classroom activities (presentations, discussions, questioning, asking questions (why, how, what, what is the rationale, what are the criteria, what if, what is the relation to ...., how to compare with ...), make important notes.

\begin{tabular}{llll}
\hline $\begin{array}{l}\text { Phase 3: } \\
\text { Checking }\end{array}$ & 1. $\begin{array}{l}\text { Helping students to check or monitor their } \\
\text { learning progress }\end{array}$ & $\begin{array}{l}\text { Students check/monitor whether the } \\
\text { planning has been done, assess the }\end{array}$ \\
& 2. $\begin{array}{l}\text { Helping students to reflect themselves on } \\
\text { understanding the material that has been } \\
\text { learning, check whether the learning } \\
\text { method has been used effectively, do I } \\
\text { understand enough material to teach to }\end{array}$ \\
& $\begin{array}{l}\text { Help students find the barriers encountered } \\
\text { during learning and find alternative solutions }\end{array}$ & $\begin{array}{l}\text { other friends?, What obstacles I } \\
\text { encountered in learning, what do I need to }\end{array}$ \\
\hline
\end{tabular}




\begin{tabular}{|c|c|c|}
\hline Step & Lecturer activities & Students activities \\
\hline & & $\begin{array}{l}\text { do in order not to happen in the next } \\
\text { lesson? }\end{array}$ \\
\hline $\begin{array}{l}\text { Phase 4: } \\
\text { Assessing and } \\
\text { Following-up }\end{array}$ & $\begin{array}{l}\text { 1. Assess student learning progress } \\
\text { 2. Evaluate whether the planned learning } \\
\text { objectives are achieved (if not yet what } \\
\text { needs to be done) } \\
\text { 3. Together the students plan the next learning } \\
\text { activity }\end{array}$ & $\begin{array}{l}\text { Students with lecturer tested an } \\
\text { understanding of the material they learned. } \\
\text { Have the objectives of formulated and } \\
\text { mutually agreed learning been achieved? } \\
\text { Should additional tasks be given to } \\
\text { improve understanding? What will be done } \\
\text { at the next meeting? }\end{array}$ \\
\hline
\end{tabular}

Learning strategies (MLS) that have been developed and validated were implemented in organic chemistry learning. One of the objectives of applying this learning strategy is to improve students' metacognition. The improvement of students' metacognition was observed with instruments developed by Schraw \& Dennison (1994), the metacognitive Awareness Inventory (MAI).
Increased student metacognition was observed by calculating the increase (N-gain score $/<\mathrm{g}>$ ) before and after learning with MLS. The metacognition scores of students before and after learning are presented in Figure 2. N-gain scores $(<\mathrm{g}>)$ for each metacognition component are presented in Table 5.

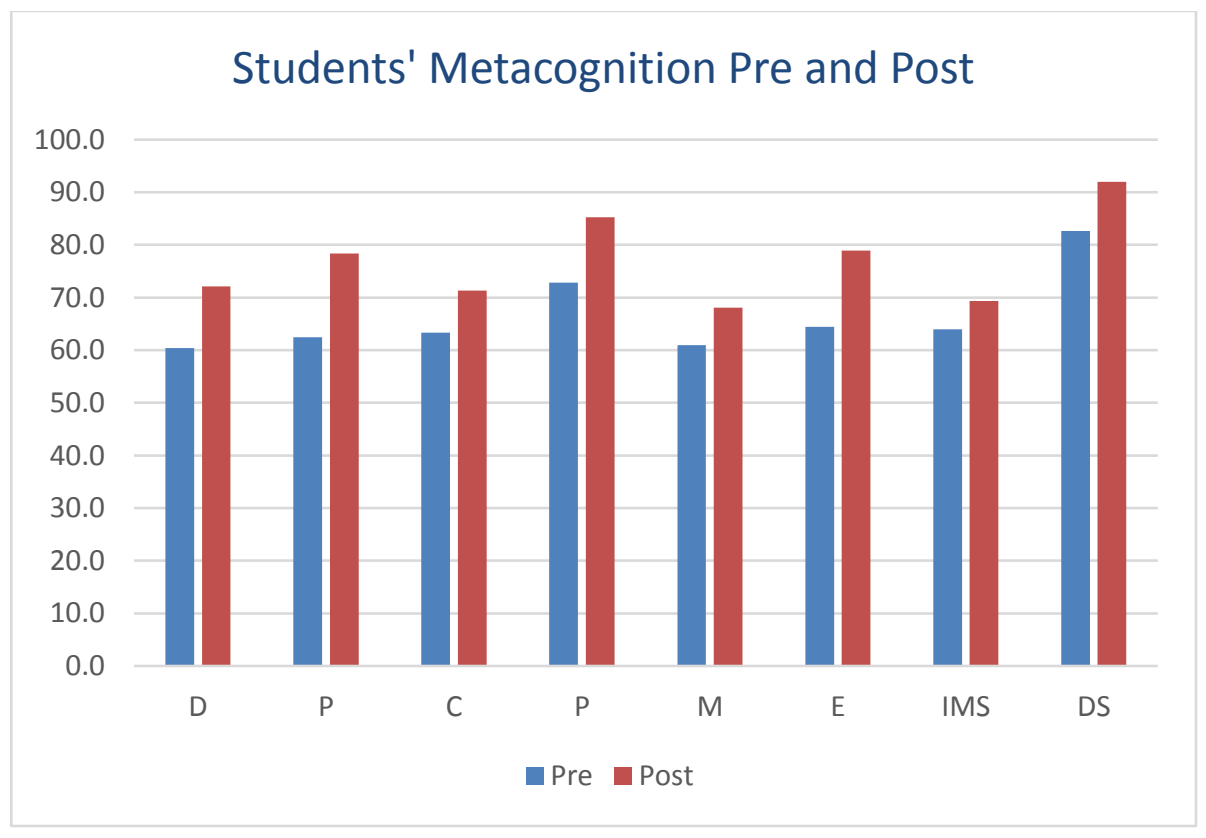

Figure 2 Metacognition score of students before and after learning

Table 5 Gain score for each metacognition component 


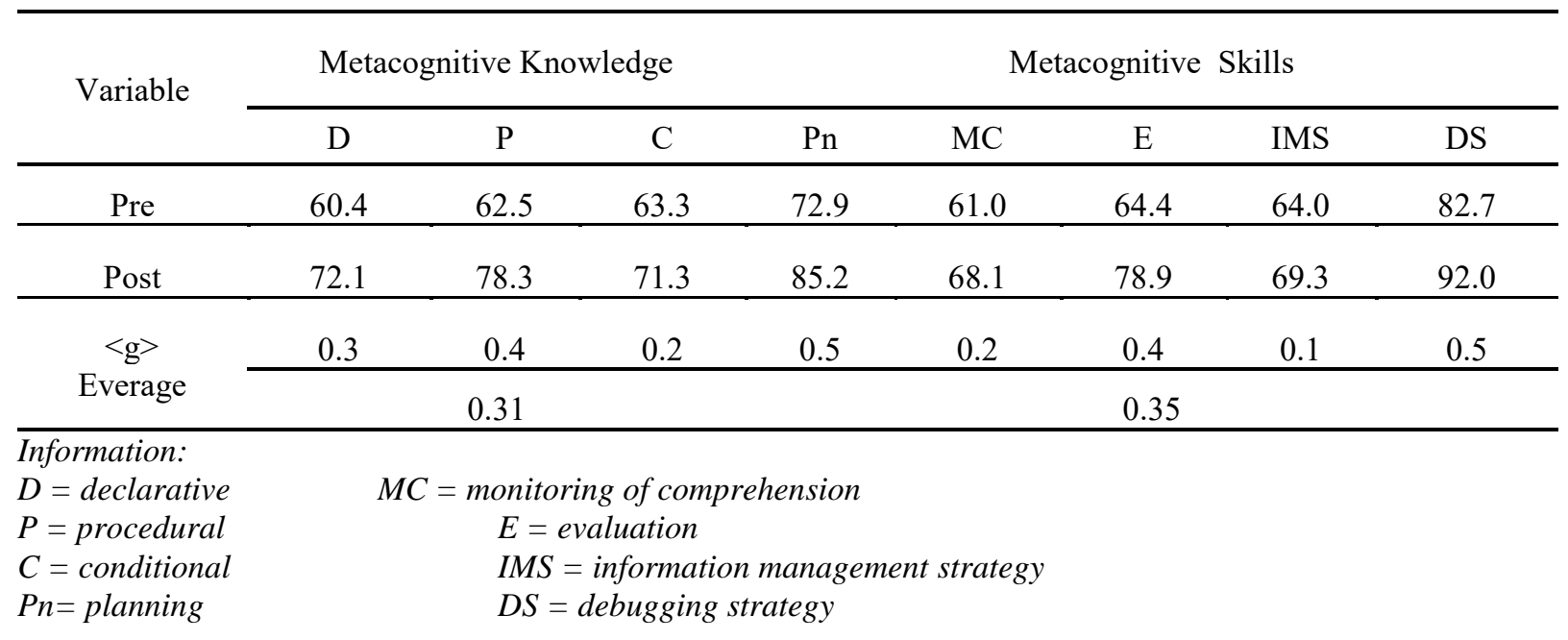

Based on Figure 2 note that there were increase in students' metacognition after attending the learning with MLS for each component of metacognition. Before students recognize new concepts to be studied, related in with the knowledge that they have been mastered, and develops a learning plan. These activities will activate his cognition so as to develop his metacognitive knowledge. Attempts to recognize prerequisite knowledge are part of meaningful learning, because meaningful learning occurs when the material being studied relates to the already understood matter (Ausuble, 1968). Connect new information with existing information and choose a strategy of thinking including basic metacognitive strategies (Blakey \& Spence, 1990).

In the early stages students also identify the learning objectives followed by choosing a learning strategy that is appropriate to the characteristics of the material being studied. Successful learners are active learners, directed toward goals and responsible for learning (APA, 1997). Learning that focuses on thinking skills provides opportunities for students to engage in task planning, be creative, and reflective (Vickery, 2014).

In the classroom students were actively involved in learning through discussions, questionsanswers, presentations, arguments with other friends or with lecturer. Lecturer provided facilities (materials), suitable physical conditions, and the atmosphere of learning to happen active learning so that the transfer and thinking process (Koenig et al., 2008). At this stage students applied active learning that has been planned in the previous stage. Metacognitive strategy is one of the application of active learning that facilitates the students to reflect the learning process to achieve the learning objectives (Rahman, et al., 2011). The involvement of students in discussion and question and answer activities encouraged the construction of the concepts they learned. According to Vygotsky, knowledge is constructed when students engage socially in discussions, experiments, and experiences (Driver, et al., 1994).

During the learning activities the students also checked their understanding and evaluated the progress of the completion of their tasks. These activities were metacognitive activities. Monitoring activities during learning, testing understanding, revising, and evaluating the effectiveness of the strategies used is one of the efforts to direct learning (Hammond, et al., 2014). Monitoring includes assessment of learning, understanding, and strategies used (Schraw \& Dennison, 1994).

At the end of the learning activities students and lecturers evaluated their learning. Evaluation is one of the metacognitive arrangements (Cooper \& Urena, 2009). In this process the student monitors whether the learning objectives have been achieved. Monitoring the achievement of goals is part of selfregulatory learning (Metcalfe, 2002).

In the learning activities, students involved in the process of planning the learning, monitoring the learning process, monitoring the understanding, and evaluating the achievement of learning objectives. These activities are repeated in every learning activity so that their metacognitive skills were increased. Based on the above description and taking into account the detailed learning activities presented in Table 4, it can be understood that the application of MLS could improve students' metacognition.

\section{CONCLUSION}


The metacognitive learning strategy (MLS) which has been developed consists of four stages: preparing, doing, checking, and assessing \& following-up (PDCA). These four phases occur repeatedly as a cycle in every lesson. Metacognition of Chemistry Education Students (CES) could be improved using PDCA's MLS with gain score $(<\mathrm{g}>)$ of 0.32 and 0.35 for metacognitive knowledge and metacognitive skills respectively.

\section{REFERENCES}

[1] Akkar, E., Takkaya, C., Çakiroğlu, J. 2011. The Interplay Between Metacognitive Awareness and Scientific Epistemological Beliefs. International Journal on New Trends in Education and Their Implications. Volume: 2 Issue: 3. pp. 7-13.

[2] APA. 1997. Learner-Centered Psychological Principles: A Framework For School Reform \& Redesign. American Psychological Association's.

[3] Ausubel, D. P. (1968). Educational psychology: A cognitive view. New York: Holt, Rinehart, \& Winston.

[4] Beal, L. 2012. Metacognition: The Effects of Cognitive Strategy Instruction on The Problem-Solving Skills of High School Algebra 2 Students. A professional paper submitted in partial fulfillment of the requirements for the degree of Master of Science. Bozeman, Montana: Montana State University.

[5] Blakey, E. \& Spence, S. 1990 Developing metacognition. ERIC Digests. Available online at: http://www.ericfacility. net/ericdigests/ed327218.html (accessed 30 November 2014).

[6] Bransford, J., Brown, A., \& Cocking, R. 2000. How People Learn: Brain, Mind, and Experience \& School. Washington, DC: National Academy Press.

[7] Cook , E., Kennedy, E., \& McGuire, S.Y. 2013. Effect of Teaching Metacognitive Learning Strategies on Performance in General Chemistry Courses. J. Chem. Educ., 90 (8), pp $961-$ 967.

[8] Cooper, M.M. \& Urena, S.S. 2009. Design and Validation of an Instrument To Assess Metacognitive Skillfulness in Chemistry Problem Solving. J. Chem. Educ., 86 (2), p 240.

[9] Cooper, M.M., Corley, L.M., \& Underwood, S.M. 2013. An Investigation of College Chemistry Students' Understanding of Structure-Property Relationships Journal of Research In Science Teaching. Vol. 50, No. 6, Pp. 699-721.

[10]De Backer, Liesje; Van Keer, Hilde; Valcke, Martin. 2012. Exploring the Potential Impact of Reciprocal Peer Tutoring on Higher Education Students' Metacognitive Knowledge and Regulation. An International Journal of the Learning Sciences, Vol 40 No 3 pp: 559-588.

[11]Delvecchio, F. 2011. Students" Use Of Metacognitive Skills While Problem Solving in High School Chemistry. A Thesis Submitted to The Faculty Of Education. Queens' University Kingston, Ontario, Canada.

[12]Driver, R., Asoko, H., Leach, J., Mortimer, E., \& Scott, P. 1994. Constructing Scientific Knowledge in the Classroom. Educational Reseacher, 23 (7): 5-12.

[13]Flick, L.B., \& Tomlinson, M. 2006. Helping students understand the minds-on side of learning science. In McMahon, M., Simmons, P., Sommers, R., DeBaets, D. \& Crawly, F. (Eds.) Assessment in Science: Practical Experiences in Educational Research (pp 183-196): Arlington, VA: NSTA Press

[14]Hammond, D. L., Austin, K., Cheung, M., \& Martin, D. 2014. Thinking about thinking: Metacognition. Accessed 8
November 2014 <http://www. learner. org /courses /learning classroom/support/09_metacog.pdf>.

[15]Kipnis, M. \& Hofstein, A. (2008). The inquiry laboratory as a source for development of metacognitive skills. International Journal of Science and Mathematics Education. 6, 601-627.

[16]Koenig, K., Frey, M., Detterman, D., 2008. ACT and General Cognitive Ability. doi:10.1016/j.intell.2007.03.005

[17] Metcalfe, J. (2002). Is study time allocated selectively to a region of proximal learning? Journal of Experimental Psychology: General, 131, 349-363.

[18]NSTA. 2012. Standards for Science Teacher Preparation. Available: http://www. nsta.org/ preservice/docs/NSTAstandards2003.pdf [30 June 2014].

[19]Pintrich, P. R., \& De Groot, E. V. 1990. Motivation and self regulated learning components of classroom academic performance. Journal of Educational Psychology, 82: 33 - 40.

[20]Rahman, S., Yasin, R.M., Jussof, K., Ariffin, S.R., Hayati, N., \& Yusof, S. 2011. The Promotion of Metacognitive Development in the Classroom. World Applied Science Journal. 13 (1): 95-99.

[21] Schraw, G., Crippen, K.J., and Hartley, K. 2006. Promoting Self-Regulation in Science Education: Metacognition as Part of a Broader Perspective on Learning. Research in Science Education 36: 111-139.

[22] Schraw, G. \& Dennison, R.S. 1994. Assessing Metacognitive Awareness. Contemporary Educational Psychology, 19, 460475.

[23] Schraw, G. \& Moshman, D. 1995. Metacognitive theories. Educational psychology Review, 7,351-373.

[24] Slavin, R. E. (2012). Educational Psychology: Theory and Practice (10th ed.). Boston: Pearson Education, Inc.

[25] Smith, K. C. \& Nakhleh, M. B. 2011. University Students' Conceptions of Bonding in Melting and Dissolving Phenomena. Chemistry Education Research and Practice, v12 n4 p398-408.

[26]Talli, L.A. \& Dar, I.A. 2014. Metacognitive Strategy Usage of Primary School Teacher Trainees In Relation To Their Gender. International Journal of English Language, Literature and Humanities. Volume 1 Issue V. 147-165.

[27] Temel, S., Ozgurb, S.D., Senc, S., Yilmazd, S. 2012. The examination of metacognitive skill levels and usage of learning strategies of preservice chemistry teachers. Procedia - Social and Behavioral Sciences 46 ( 2012 ) 1445 - 1449.

[28]Thiagarajan, S., Semmel, D.S \& Semmel, M.I. 1974. Instructional Development for Training Teachers of Exceptional Children. Blommington: Indiana University.

[29] Thomas G. P. 2003. Conceptualization, Development, and Validation of An Instrument for Investigating The Metacognitive Orientation of Science Classroom Learning Environments: The Metacognitive Orientation Learning Environment Scale-Science (Moles-S). Learning Environments Research 6: 175-197.

[30] Vickery, A. 2014. Developing Active Learning in The Primary Classroom. London: SAGE Publications Ltd.

[31] Wilson, N.S \& Bai, H. 2010. The relationships and impact of teachers' metacognitive knowledge and pedagogical understandings of metacognition. Metacognition Learning. Online: http://www4.ncsu.edu/.

[32] Winne P. H., Hadwin A. F. 1998. "Studying as self-regulated engagement in learning," in Metacognition in Educational Theory and Practice. Hacker D., Dunlosky J., Graesser A., editors. (Hillsdale, NJ: Erlbaum; ) 277-304. 